\title{
Correlations of survivin expression with clinicomorphological parameters and hormonal receptor status in breast ductal carcinoma
}

\author{
M. ADAMKOV ${ }^{1 *}$, K. KAJO², D. VYBOHOVA ${ }^{3}$, J. KRAJCOVIC ${ }^{4}$, F. STULLER ${ }^{4}$, J. RAJCANI ${ }^{5}$ \\ ${ }^{1}$ Department of Histology and Embryology, Jessenius Faculty of Medicine Martin, Comenius University, Malá Hora 4, 03601 Martin, Slovakia; \\ ${ }^{2}$ Department of Pathology, BB Biocyt Diagnostic Center, L. Svobodu 1, 97401 Banská Bystrica, Slovakia; ${ }^{3}$ Department of Anatomy, Jessenius \\ Faculty of Medicine Martin, Comenius University, Martin, Slovakia; ${ }^{4}$ Department of Forensic Medicine and Medical Expertises, Jessenius Faculty \\ of Medicine Martin, Comenius University, Martin, Slovakia; ${ }^{5}$ Laboratory of Pathological anatomy, Alpha medical, a.s., Hodžova 1, 03601 Martin, \\ Slovakia
}

${ }^{*}$ Correspondence: adamkov@jfmed.uniba.sk

Received May 24, 2011 / Accepted June 22, 2011

\begin{abstract}
The antiapoptotic protein survivin is widely expressed in most human cancers, including carcinomas of the breast. It is rarely detected in corresponding normal adult tissues. Therefore, survivin comes into the limelight as a promising diagnostic biomarker and prognostic parameter. Immunohistochemically, we examined the expression of this protein in 126 cases of ductal breast carcinoma to determine the association with clinicomorphological parameters such as age of patients, grade, stage and size of the primary tumor, lymph node metastasis, vascular invasion as well as estrogen and progesterone status. In each section, the subcellular location of survivin antigen, the intensity of staining and the percentage of labeled cells were assessed. Overall, survivin was expressed in 111 cases (88.1\%). The statistical analysis revealed a significant correlation between the nuclear location of survivin and tumor grade 3. Furthermore, a significant relation was also found between vascular invasion and nuclear and combined nuclear and cytoplasmic survivin expression, together with a higher intensity of immunoreaction. However, no significant correlations were shown with other clinicomorphological parameters, such as stage and size of the tumor, lymph node metastasis, estrogen and progesterone receptors and age. Our findings revealed that survivin was frequently overexpressed in carcinoma cells, where it was present in different subcellular compartments. The nuclear positivity of survivin or combined nuclear and cytoplasmic expression was shown to be a poor prognostic parameter in ductal breast carcinoma.
\end{abstract}

Key words: breast, carcinoma, survivin, clinicomorphological parameters

Survivin is a unique member of the inhibitor of apoptosis protein (IAP) family. So far eight human IAP family members were identified: C-IAP1, C-IAP2, NAIP, ILP-2, XIAP, apollon, ML-IAP/livin and survivin [1,2]. Multifunctional survivin possesses a number of distinct features not shared with other IAP members: it regulates cell division, inhibits apoptosis (programmed cell death) and enhances angiogenesis. Except for these features, survivin is not detectable in the majority of normal terminally differentiated adult tissues. Nevertheless, it is frequently expressed in embryonic and fetal organs as well as in developed human malignancies $[3,4,5]$. Survivin can be detected in different subcellular compartments. Therefore, it is currently undergoing intense investigation as a potential tumor marker and prognostic factor $[4,6,7,8]$. Conflicting data have been published about the prognostic value of this protein in question in different types of malignant tumors, including breast cancers $[9,10,11,12,13]$. Review of literature shows that the location of survivin expression is still a matter of discussion [13]. As described previously, there are three patterns of survivin immunohistochemical positivity in malignant cells: nuclear, cytoplasmic and combined (nucleus and cytoplasm) $[14,15,16,17]$. However, the reason for subcellular compartmentalization of survivin in neoplastic tissues is not yet fully understood. There is a growing evidence that several oncogenic pathways are potentially involved in the up-regulation of survivin protein in malignant lesions [18]. Certain novel studies strictly differentiate the location of survivin in malignant cells $[19,20]$. In spite of some disagreement, several research groups found that nuclear expression of survivin in breast cancer correlates with poor prognosis [19,21,22]. Many 
other morphological parameters, such as histological type, grading, tumor size, mitotic rate, vascular invasion and lymph node metastasis, were regarded predictive for the prognosis of malignant breast tumor $[23,24,25,26,27,28,29,30]$. Furthermore, the prognosis may be influenced by a number of other significant variables, including hormonal receptor status, race, age and family history $[23,24,25,26,27]$.

The purpose of this study is to evaluate survivin expression levels in ductal breast carcinoma tissue by using immunohistochemistry and to determine the association between survivin cellular location and histomorphological parameters. The hormonal receptor status is also studied in respect to the expression of protein in question.

\section{Material and methods}

Formalin-fixed paraffin-embedded tissue samples from 126 cases of invasive ductal carcinoma were included in the present study. Hematoxylin and eosin stained slides from all cases were reviewed by two pathologists (KK, $\mathrm{MA})$ to confirm the diagnosis. Each representative paraffin block was cut into four micrometer sections subjected to immunohistochemical staining where three sections from each one have been stained for survivin protein. For greater adherence of tissue sections to glass slides, silanized slides (DAKO, Denmark) were used, which had been baken for two hours in an oven at $56^{\circ} \mathrm{C}$. The sections were then deparaffinized in xylene for 20 minutes, rehydrated at decreasing ethanol concentrations and washed with phosphate-buffered saline (PBS). The endogenous peroxidase activity was quenched with $3 \%$ hydrogen peroxide for 30 minutes. Antigen unmasking was achieved by heating the sections, which had been previously immersed into target solution (DAKO) within a hot water bath $\left(96^{\circ} \mathrm{C}\right.$, for 45 minutes). Immunohistochemical staining was performed using monoclonal mouse anti-survivin antibody (DAKO, Clone12C4, dilution 1:50). Following an overnight incubation, the immunodetection was completed using the LSAB Vizualization System (DAKO) utilizing 3, 3' - diaminobenzidine chromogen as substrate, according to the manufacturer's instructions. All sections were counterstained with hematoxylin (DAKO). Negative controls were obtained by omitting the primary antibody.

In each case, the following parameters were assessed:

1) the intensity of staining, 2) the relative number of positively stained cells and 3 ) the subcellular localization of survivin antigen.

To achieve good reproducibility, the above mentioned parameters were evaluated semiquantitatively by two observers separately (MA, JR), who scored them using unified and clear cut-off criteria.

The age of patients, grade, stage and size of the tumor, lymph node metastasis, vascular invasion, estrogen and progesterone receptors status were designated as clinicomorphological parameters.
Statistical analysis. Statistical evaluation was performed with Microsoft Excel software package. Chi - square $\left(\chi^{2}\right)$ test was used to demonstrate the correlation between survivin expression and clinicopathological parameters of invasive ductal cancer as well as between histological grade and clinicopathological parameters. $P$ value less than 0.05 was considered to indicate a statistical significance.

\section{Results}

Evaluation of immunohistochemical staining. In our group of 126 ductal carcinoma cases, survivin was expressed in 111 cases $(88.1 \%)$. The positive cases showed a variable subcellular localization. Cytoplasmic staining was detected in 18 out of 126 cases (14.3\%), while solely nuclear positivity was observed in 22 out of 126 cases (17.5\%). Combined (nuclear as well as cytoplasmic) expression of survivin was demonstrated in 71 out of 126 cases (56.3\%). In those cells with combined expression, the survivin localization was found predominantly cytoplasmic. Furthermore, the majority of cells in these cases expressed cytoplasmic immunoreaction (Fig. 1B). At higher magnification, nuclear staining exhibited a punctuate pattern (Fig. 1A) and also the nucleoli often showed survivin immunopositivity. The pattern of cytoplasmic staining was either granular, diffuse or both (Fig. 1C). Due to the fact that carcinoma cells frequently expressed heterogenic survivin immunoreactivity, this dominant pattern was used for scoring.

Statistical analysis results. Clinicopathological findings in the invasive ductal cancer cases (age, histological grade, tumor size and stage, lymph node metastasis, vascular invasion and expression of estrogen and progesterone receptors) were confronted with the immunohistochemical characterization of survivin expression - i.e. its subcellular localization, the intensity of immunostaining and the percentage of survivin positive cells (Table 1). The cases with absent survivin expression were also included in the statistical analysis of all immunohistochemical characteristics of survivin.

The statistical analyses revealed a significant correlation between the tumor grade and the subcellular localization of survivin $(p<0.05)$. Grade 3 was significantly associated with nuclear localization of survivin. It was demonstrated in only $6.3 \%$ of cases with grade 1 and $5.8 \%$ with grade 2, while in $30 \%$ of cases with grade 3 .

Furthermore, another statistically significant correlation was confirmed also between the vascular invasion in tumor and subcellular localization of survivin $(\mathrm{p}<0.01)$. Specimens with positive vascular invasion showed nuclear and combined (both nuclear and cytoplasmic) expression of survivin in $86.7 \%$ of cases. A higher intensity of survivin immunoreactivity was also statisticaly related to the appearance of vascular tumor invasion.

The other clinicopathological parameters (such as age, tumor size and stage, lymph node metastasis, estrogen and progester- 
A

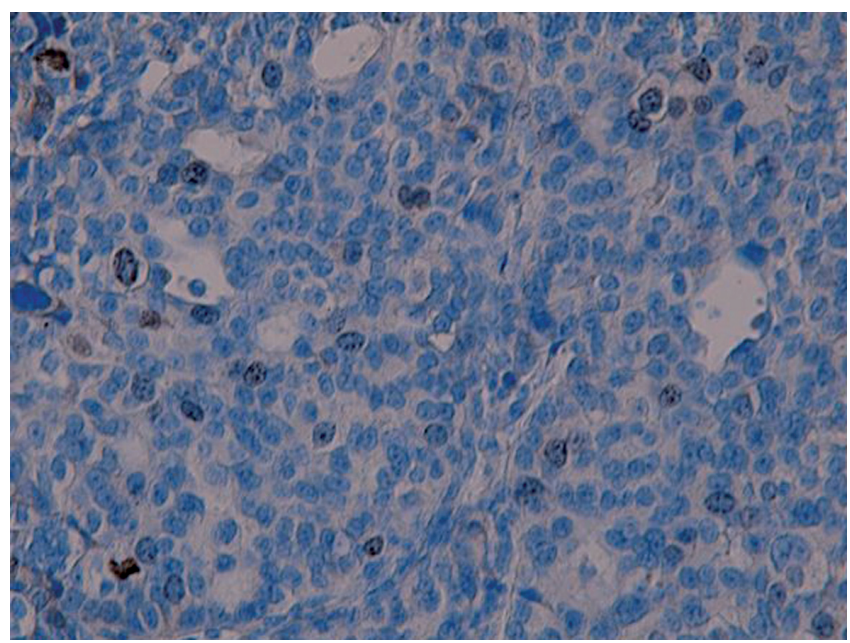

C

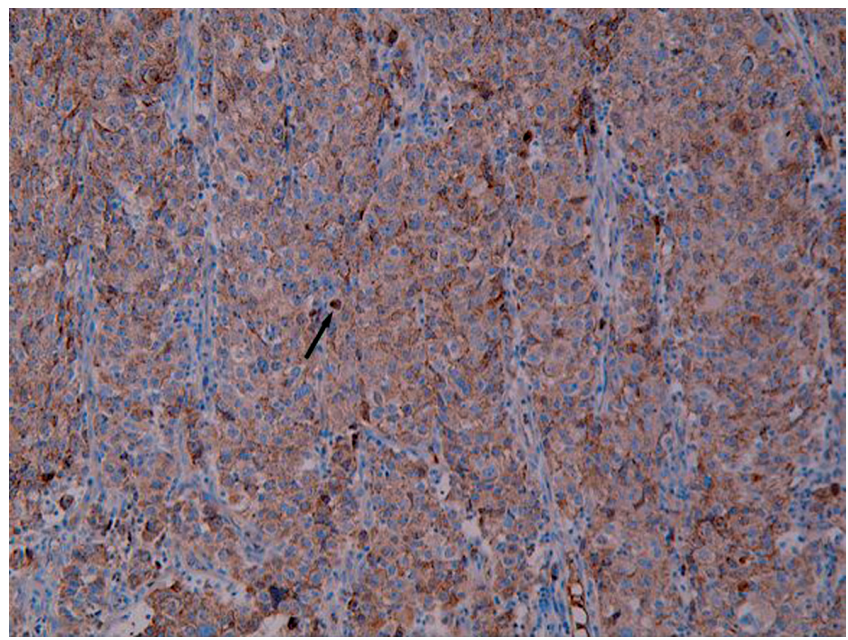

one receptors) did not correlate with the immunohistochemical characterization of survivin expression ( $p>0.05$; Table 1).

The comparison of histological grade and clinicopathological parameters (age, tumor size and stage, lymph node metastasis, vascular invasion and expression of estrogen and progesterone receptors) is summarized in Table 2. The $\chi^{2}$ test confirmed that in all our invasive ductal carcinoma cases, the histological grade was significantly correlated with the tumor size and stage, lymph node metastasis, vascular invasion and expression of the estrogen and progesterone receptors $(\mathrm{p}<0.01)$.

Tumors over $20 \mathrm{~mm}$ in size were with a probability of $55.4 \%$ grade 3 tumors, but only with $3.3 \%$ probability grade 1 tumors. All grade 1 ductal cancers were at stage T1, whereas $22.2 \%$ of grade 3 cases were at stage T4.

Lymph nodes were positive for metastases in only $11.1 \%$ of the grade 1 tumors and $12.1 \%$ of the grade 2 tumors, while
B

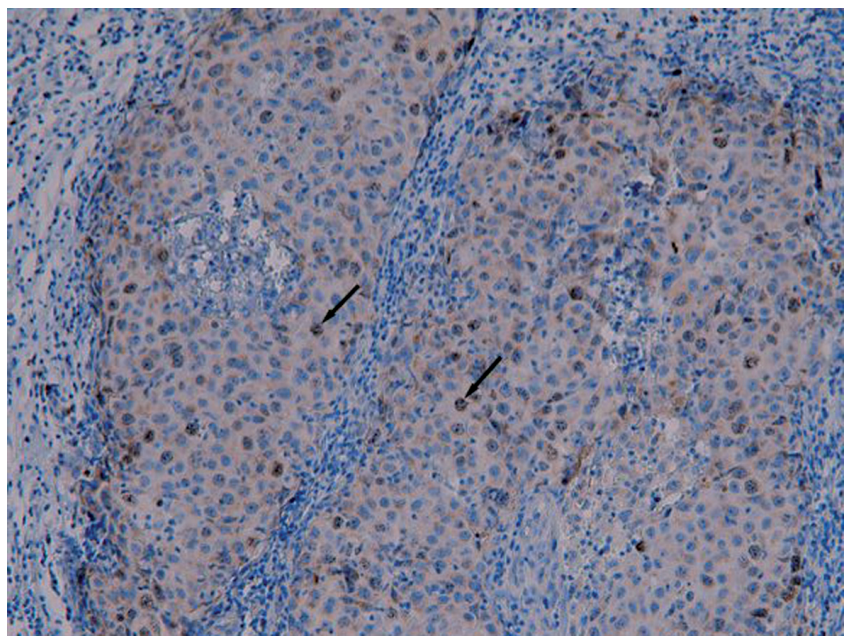

Figure 1. Expression of survivin in breast ductal carcinoma.

A. Solely nuclear staining showing punctuate pattern in carcinoma cells (original magnification: $x 400$ )

B. Combined nuclear (arrows) and cytoplasmic positivity in carcinoma cells (original magnification: $\mathbf{x} 200$ )

C. Cytoplasmic granular and diffuse reaction in carcinoma cells; single carcinoma cell with nuclear positivity (arrow) (original magnification: $\mathrm{x} 200$ )

in $45.7 \%$ of grade 3 tumors. Vascular invasion was detected in $30.0 \%$ of tumors at histological grade 1 , but in $68.5 \%$ of cases at grade 3. Expression of the estrogen and progesterone receptors in ductal carcinomas grade 1 and 2 was found out in 123 cases out of 124 total (>99\%). However, only $56.7 \%$ of the grade 3 tumors expressed estrogen receptors and 50.0\% of them showed progesterone receptors.

Noteworthy, the histological grade was not related to the age of patients $(\mathrm{p}>0.05)$.

\section{Discussion}

Breast carcinoma is still one of the most common malignant tumors in female patients. It also belongs to the leading group of lethal cancers in women. Therefore, several histomorphological and clinical parameters as well as tumor markers were 
Table 1. Clinical and pathological parameters of survivin expression

\begin{tabular}{|c|c|c|c|c|c|c|c|c|c|}
\hline \multirow[b]{2}{*}{ Survivin expression } & \multirow[b]{2}{*}{$A$} & \multicolumn{3}{|c|}{ Subcellular localization } & \multicolumn{2}{|c|}{$\begin{array}{c}\text { Intensity of immuno- } \\
\text { reactivity }\end{array}$} & \multicolumn{3}{|c|}{$\begin{array}{c}\text { Percentage } \\
\text { of labelled cells }\end{array}$} \\
\hline & & $C$ & $N$ & NC & + & $\begin{array}{c}++ \\
+++\end{array}$ & $\begin{array}{c}<10 \\
\%\end{array}$ & $\begin{array}{c}11-50 \\
\%\end{array}$ & $\begin{array}{c}>50 \\
\%\end{array}$ \\
\hline \multicolumn{10}{|l|}{ Age $(n=126)$} \\
\hline$<40$ & 0 & 0 & 0 & 1 & 0 & 1 & 0 & 1 & 0 \\
\hline $41-50$ & 2 & 4 & 4 & 17 & 11 & 14 & 3 & 4 & 18 \\
\hline $51-60$ & 3 & 5 & 5 & 21 & 12 & 19 & 4 & 8 & 19 \\
\hline $61-70$ & 3 & 5 & 5 & 14 & 7 & 17 & 1 & 8 & 15 \\
\hline$>70$ & 7 & 4 & 8 & 18 & 13 & 17 & 2 & 12 & 16 \\
\hline$p$-value & & \multicolumn{3}{|c|}{0.950} & \multicolumn{2}{|c|}{0.766} & \multicolumn{3}{|c|}{0.555} \\
\hline \multicolumn{10}{|l|}{ Grade $(n=126)$} \\
\hline 1 & 6 & 5 & 2 & 19 & 10 & 16 & 2 & 6 & 18 \\
\hline 2 & 4 & 7 & 2 & 21 & 16 & 14 & 3 & 7 & 20 \\
\hline 3 & 5 & 6 & 18 & 31 & 17 & 38 & 5 & 20 & 30 \\
\hline$p$-value & & \multicolumn{3}{|c|}{0.025} & \multicolumn{2}{|c|}{0.175} & \multicolumn{3}{|c|}{0.587} \\
\hline \multicolumn{10}{|l|}{ Tumour size $(n=120)$} \\
\hline$<11 \mathrm{~mm}$ & 5 & 3 & 2 & 16 & 9 & 12 & 2 & 6 & 13 \\
\hline $11-20 \mathrm{~mm}$ & 5 & 11 & 9 & 28 & 20 & 28 & 4 & 15 & 29 \\
\hline$>20 \mathrm{~mm}$ & 5 & 3 & 11 & 22 & 12 & 24 & 4 & 12 & 20 \\
\hline p-value & & \multicolumn{3}{|c|}{0.239} & \multicolumn{2}{|c|}{0.682} & \multicolumn{3}{|c|}{0.927} \\
\hline \multicolumn{10}{|l|}{ Stage $(n=121)$} \\
\hline$T 1$ & 8 & 14 & 11 & 46 & 28 & 43 & 6 & 20 & 45 \\
\hline$T 2$ & 4 & 2 & 5 & 14 & 7 & 14 & 1 & 9 & 11 \\
\hline T3 & 1 & 0 & 1 & 0 & 0 & 1 & 0 & 1 & 0 \\
\hline$T 4$ & 2 & 1 & 4 & 8 & 5 & 8 & 2 & 3 & 8 \\
\hline p-value & & \multicolumn{3}{|c|}{0.440} & \multicolumn{2}{|c|}{0.691} & \multicolumn{3}{|c|}{0.607} \\
\hline \multicolumn{10}{|l|}{ LN metastasis ( $n=99)$} \\
\hline positive & 2 & 3 & 6 & 17 & 8 & 18 & 3 & 5 & 18 \\
\hline negative & 10 & 10 & 12 & 39 & 25 & 36 & 6 & 23 & 32 \\
\hline p-value & & \multicolumn{3}{|c|}{0.725} & \multicolumn{2}{|c|}{0.418} & & 0.275 & \\
\hline Vascular invasion ( $n=$ & & & & & & & & & \\
\hline positive & 4 & 4 & 15 & 37 & 17 & 39 & 7 & 16 & 33 \\
\hline negative & 10 & 12 & 6 & 27 & 21 & 24 & 2 & 17 & 26 \\
\hline p-value & & & 0.008 & & & & & 0.111 & \\
\hline $\boldsymbol{E R}(n=124)$ & & & & & & & & & \\
\hline positive & 11 & 17 & 15 & 54 & 36 & 50 & 7 & 24 & 55 \\
\hline negative & 3 & 1 & 7 & 16 & 7 & 17 & 3 & 9 & 12 \\
\hline p-value & & & 0.248 & & & & & 0.666 & \\
\hline$P R(n=124)$ & & & & & & & & & \\
\hline positive & 13 & 13 & 14 & 53 & 33 & 47 & 6 & 23 & 51 \\
\hline negative & 2 & 4 & 8 & 17 & 9 & 20 & 4 & 10 & 15 \\
\hline$p$-value & & & 0.450 & & & & & 0.397 & \\
\hline
\end{tabular}

survivin expression: $A$ - absent, $C$-cytoplasmic, $N$-nuclear, $N C$-combined $(N+C)$

$L N$ - lymph node

ER - estrogen receptors

$P R$ - progesterone receptors

Note: the significant relationship is shown in bold type

reported to have prognostic significance in these patients $[11,31,32,33]$. From these, the histological grade of tumor, number of metastatic lymph nodes, tumor size, vascular invasion and tumor stage were found to be the most important histomorphological prognostic parameters widely accepted and used in daily practice. Estrogen and progesterone receptor status and Her-2/neu should also belong to the routinely performed markers for the assessment of prognosis and therapeutic management of breast carcinoma patients [34]. Among these tumor markers, the antiapoptotic protein survivin was 
Table 2. Histological grading as compared with clinical and pathological parameters

\begin{tabular}{|c|c|c|c|}
\hline \multirow{2}{*}{$\begin{array}{l}\text { Clinicopathological } \\
\text { parameters }\end{array}$} & \multicolumn{3}{|c|}{ Histological grade } \\
\hline & 1 & 2 & 3 \\
\hline \multicolumn{4}{|l|}{$\operatorname{Age}(n=126)$} \\
\hline$<40$ & 0 & 0 & 1 \\
\hline $41-50$ & 5 & 8 & 14 \\
\hline $51-60$ & 7 & 9 & 18 \\
\hline $61-70$ & 6 & 12 & 9 \\
\hline$>70$ & 14 & 5 & 18 \\
\hline$p$-value & 0.182 & & \\
\hline \multicolumn{4}{|l|}{ Tumour size $(n=120)$} \\
\hline$<11 \mathrm{~mm}$ & 14 & 9 & 3 \\
\hline $11-20 \mathrm{~mm}$ & 15 & 16 & 22 \\
\hline$>20 \mathrm{~mm}$ & 1 & 9 & 31 \\
\hline$p$-value & $1.32 E-06$ & & \\
\hline \multicolumn{4}{|l|}{$\operatorname{Stage}(n=121)$} \\
\hline$T 1$ & 32 & 26 & 21 \\
\hline$T 2$ & 0 & 4 & 21 \\
\hline T3 & 0 & 0 & 2 \\
\hline T4 & 0 & 3 & 12 \\
\hline$p$-value & $6.61 E-07$ & & \\
\hline \multicolumn{4}{|l|}{ LN metastasis $(n=99)$} \\
\hline positive & 3 & 4 & 21 \\
\hline negative & 24 & 23 & 24 \\
\hline$p$-value & 0.001 & & \\
\hline \multicolumn{4}{|c|}{ Vascular invasion $(n=115)$} \\
\hline positive & 9 & 14 & 37 \\
\hline negative & 21 & 17 & 17 \\
\hline$p$-value & 0.002 & & \\
\hline \multicolumn{4}{|l|}{ ER $(n=124)$} \\
\hline positive & 30 & 33 & 34 \\
\hline negative & 1 & 0 & 26 \\
\hline$p$-value & $1.23 E-07$ & & \\
\hline \multicolumn{4}{|l|}{$\boldsymbol{P R}(n=124)$} \\
\hline positive & 31 & 33 & 30 \\
\hline negative & 0 & 0 & 30 \\
\hline$p$-value & $6.82 E-10$ & & \\
\hline
\end{tabular}

$L N-$ lymph node

$E R$ - estrogen receptors

$P R$ - progesterone receptors

found to be representing an attractive diagnostic marker as well as a novel prognostic factor [14]. The mRNA for antiapoptotic protein survivin is the fourth most frequently expressed transcript in common cancers [14]. Despite this, much more papers deal with the expression of other proteins in malignant tumors, such as $\mathrm{p} 53$ and $\mathrm{Bcl}-2$, rather than with survivin, though the search for survivin has certainly opened new research directions. In this study, we investigated the subcellular expression of survivin and possible correlations of its different subcellular pools with the above mentioned clinicomorphological parameters and hormonal receptor status.

Currently, there is a heated discussion within literature concerning the relationship of survivin with several his- topathological and clinical parameters in breast carcinomas. Al-Joudi et al. [35] found a significant correlation between survivin expression and the tumor size and lymph node involvement. However, no significant correlations were shown with other data, such as the tumor histological grade, and estrogen and progesterone receptors. Sohn et al. [36] reported that cytoplasmic survivin expression was correlated with the stage, histological grade and lymph node metastasis. On the other hand, survivin nuclear expression correlated significantly with the histological grade and tumor stage, and also tended to correlate with estrogen receptor $(\mathrm{P}=0.050)$ in the study of Nassar et al. [32]. According to others, no significant correlations were found between survivin and the tumor size, tumor grade, nodal status, histology type and hormone receptor status $[31,37]$. Furthermore, Ryan et al. [37] studied survivin expression and its splice variants survivin- $2 \mathrm{~B}$ and survivin- $\triangle \mathrm{Ex} 3$ in breast carcinomas, but no significant correlation was revealed between any of the investigated survivin forms and the above mentioned clinicopathological parameters. In our group of 126 invasive ductal carcinomas, we demonstrated a positive correlation between nuclear survivin localization and tumor histological grade 3. Furthermore, nuclear, combined nuclear and cytoplasmic survivin expression, and its higher intensity of immunohistochemical reaction, were significantly correlated with lymphovascular invasion. Both histological grade 3 and lymphovascular invasion are considered to be poor prognostic parameters.

The histological grade of a tumor is one of the most important prognostic factors and together with the age and menopausal status of the patient, the stage of disease, the ER and PR status of the tumor, the proliferative capacity of the tumor and HER2/neu gene amplification may influence therapy selection [38]. Malignant tumors, in contrast to their benign counterparts, demand a much more comprehensive and detailed description. One of the major tasks is to grade the tumor according to its differentiation. Malignant tumors are usually graded as either well (grade 1), moderately (grade 2 ) or poorly (grade 3 ) differentiated. In general, well differentiated tumors are less aggressive than their poorly differentiated counterparts. In our panel of 126 ductal carcinomas, 60 cases $(47.6 \%)$ were diagnosed as grade 3,34 cases $(27.0 \%)$ as grade 2 and 32 cases $(25.4 \%)$ as grade 1 . In the group of grade 3 carcinomas, combined NC immunopositivity (31 cases $/ 51.7 \%$ ) was the most frequent. However, overall nuclear reaction $(\mathrm{N}, \mathrm{NC})$ in this group was found in 49 cases (81.7\%). Our findings in ductal breast carcinomas showed that nuclear and combined nuclear as well as cytoplasmic survivin expression may be associated with histological grade 3 .

The lymphovascular and venous drainages of the breast play an important role in the spread of primary carcinoma. Approximately three quarters of the lymphatics reach the axillary lymph nodes. There are free communications between lymph nodes above and below clavicle as well as between axillary and cervical nodes. Other connections also lead to the contralateral breast tissue. Moreover, the connections of the vertebral plexus 
with intercostals veins permit the development of metastases in the nervous system and bones [39]. Therefore, histological assessment of the lymphovascular and vascular invasion represents an important source of prognostic information. In general, conflicting data were reported on survivin expression and its association with the lymphovascular invasion. Some authors concluded that survivin expression correlated with the invasion of lymphatics [40], while other papers described no correlation $[20,31]$. Our results showed a significant relationship between the vascular invasion and subcellular compartmentalization of survivin and a higher intensity of immunoreaction of this protein. Cases with vascular invasion showed nuclear and combined (both nuclear and cytoplasmic) survivin reaction in $86.7 \%$. Molecular mechanisms of metastatic dissemination have been elucidated in recent study of Mehrotra et al. [41]. They pointed out at intermolecular cooperation between extracellular and intracellular constituents. Interaction of two IAP proteins, survivin and XIAP, triggers cascade reaction involving NFkB (Nuclear Factor $\kappa B$ ), which leads to increased fibronectin gene expression, signaling by $\beta 1$ integrins, and activation of cell motility kinases, FAK (Focal Adhesion Kinase) and Src (proto-oncogenic tyrosine kinase). Thus, both of the above mentioned IAP proteins are required for metastatic dissemination. Therefore, these IAPs are considered as direct metastatic genes.

The significance of subcellular survivin expression in breast carcinoma is still controversial, since the research on the role of survivin as a prognostic factor leads to conflicting results $[11,19]$. Taking into account the key position of survivin in the inhibition of apoptosis, in the promotion of cell proliferation and in the induction of angiogenesis, there is an acceptable argument that the overexpression of this protein in question may be an indicator of a worse prognosis [14,42]. Indeed, multiple clinical studies showed the association of survivin expression with unfavorable prognosis, diminished survival, increased rates of relapse and chemoresistence $[43,44]$. Furthermore, many recent papers recognize the subcellular location of survivin in respect to the prognosis of breast carcinoma. The detailed study of Brennan et al. [19] concluded that different prognostic information is associated with nuclear and cytoplasmic survivin location, nuclear survivin expression being a poor prognostic marker. A multivariate analysis of 157 breast carcinomas by $\mathrm{Oh}$ et al. [33] revealed that cytoplasmic survivin expression was associated with an improved overall survival, while nuclear expression was correlated with an unfavorable overall survival. Similarly, a high cytoplasmic to nuclear ratio of survivin was associated with an improved overall survival and, conversely, an increased nuclear to cytoplasmic survivin ratio was correlated with an unfavorable overall survival. Both of our previous studies $[16,17]$ and recent results also demonstrated that nuclear and combined nuclear and cytoplasmic survivin reaction are associated with worse prognostic parameters, it is not a case of solely cytoplasmic positivity. It follows that different subcellular survivin compartmentalization has distinct functions. Generally, survivin is a nuclear shuttle protein and its dynamic localization plays a key role in cell function and regulation. Recently, it has been accepted that nuclear survivin may participate in the regulation of cell proliferation and may lead to a proliferative aggressive phenotype $[13,19,45]$. On the other hand, cytoplasmic survivin may be related to the apoptotic process and may be involved in the inhibition of cell death $[13,14,46]$ and promoting carcinogenesis [47]. Data obtained by Jin et al. [47] suggest, that cytosolic survivin expression was induced even in early carcinogenesis.

In contrast to the above mentioned correlations, we also studied the relationship between the histological grade and remaining histomorphological parameters. The statistical evaluation confirmed that tumor grade is one of the key histomorphological and prognostic factors in the assessment of breast carcinoma.

In conclusion, we indicate that different subcellular survivin expression may influence the biological behavior of the ductal breast carcinoma. We point out that only nuclear and combined nuclear and cytoplasmic positivity together with a higher intensity of survivin immunoreactivity (proliferative phenotype) are associated with poor prognostic parameters, such as tumor grade 3 and vascular invasion. Both of them are considered to be powerful prognostic factors. Based on the above mentioned findings, we can conclude that the antiapoptotic protein survivin may represent a poor prognostic marker in the ductal breast carcinoma.

Acknowledgments: We thank Mrs Margareta Kondekova, Mrs Monika Letrichova, Mrs Agata Resetarova, Mrs Jana Visnovcova and Mrs Slavka Drahosova for the skillful technical assistance. This work was supported by project VEGA 1/0050/11.

\section{References}

[1] DEVERAUX QL, REED JC IAP family proteins-suppressors of apoptosis. Genes Dev 1999; 13: 239-252. http://dx.doi. org/10.1101/gad.13.3.239

[2] AMIRI KI, RICHMOND A Role of nuclear factor-k B in melanoma. Cancer Metastasis Rev 2005; 24: 301-313. http:// dx.doi.org/10.1007/s10555-005-1579-7

[3] LI F Survivin study: what is the next wave? J Cell Physiol 2003; 197: 8-29. http://dx.doi.org/10.1002/jcp.10327

[4] LI F Role of Survivin and its Splice Variants in Tumorigenesis. Br J Cancer 2005a; 92: 212-216.

[5] LI F, BRATTAIN MG Role of the survivin gene in pathobiology. Am J Pathol 2006; 169: 1-11. http://dx.doi. org/10.2353/ajpath.2006.060121

[6] MOON WS, TARNAWSKI AS Nuclear translocation of survivin in hepatocellular carcinoma: a key to cancer cell growth? Human Pathol 2003; 34: 1119-1126. http://dx.doi. org/10.1053/j.humpath.2003.07.016

[7] VETTER CS, MÜLLER-BLECH K, SCHRAMA D, BRÖCKER EB, BECKER JC Cytoplasmic and nuclear expression of survivin in melanocytic skin lesions. Arch Dermatol Res 2005; 297: 26-30. http://dx.doi.org/10.1007/s00403-005-0572-x 
[8] DING Y, PRIETO VG, ZHANG PS, ROSENTHAL S, SMITH KJ et al. Nuclear expression of the antiapoptoptic protein survivin in malignant melanoma. Cancer 2006; 106: 1123-1129. http://dx.doi.org/10.1002/cncr.21727

[9] TANAKA K, IWAMOTO S, GON G, NOHARA T, IWAMOTO $\mathrm{M}$ et al.:Expression of survivin and its relationship to loss of apoptosis in breast carcinomas. Clin Cancer Res 2000; 6: 127134.

[10] CHU JS, SHEW JY, HUANG CS Immunohistochemical analysis of survivin expression in primary breast cancers. J Formos Med Assoc 2004; 103: 925-931.

[11] KENNEDY SM, O'DRISCOLL L, PURCELL R, FITZ-SIMONS N, MCDERMOTT EW et al. Prognostic importance of survivin in breast cancer. Br J Cancer 2003; 88: 1077-1083. http://dx.doi.org/10.1038/sj.bjc.6600776

[12] SPAN PN, SWEEP FCGJ, WIEGERINCK ETG, TJAN-HEIJNEN VCG, MANDERS P et al. Survivin is an independent prognostic marker for risk stratification of breas cancer patients. Clin Chem 2004; 50: 1986-1993. http://dx.doi.org/ 10.1373/clinchem.2004.039149

[13] LI F, YANG J, RAMNATH N, JAVLE MM, TAN D Nuclear or cytoplasmic expression of survivin: What is the significance? Int J Cancer 2005b; 114: 509-512. http://dx.doi.org/10.1002/ ijc. 20768

[14] DUFFY MJ, O'DONOVAN N, BRENNAN DJ, GALLAGHER WM, RYAN BM Survivin: A promising tumor biomarker. Cancer Lett 2007; 249: 49-60. http://dx.doi. org/10.1016/j.canlet.2006.12.020

[15] PIRAS F, MURTAS D, MINERBA L, UGALDE J, FLORIS C et al. Nuclear survivin is associated with disease recurrence and poor survival in patients with cutaneous malignant melanoma. Histopathology 2007; 50: 835-842. http://dx.doi. org/10.1111/j.1365-2559.2007.02695.x

[16] ADAMKOV M, LAUKO L, RAJCANI J, BALENTOVA S, RYBAROVA $S$ et al. Expression of antiapoptotic protein survivin in malignant melanoma. Biologia 2009a; 64: 840-844. http://dx.doi.org/10.2478/s11756-009-0134-3

[17] ADAMKOV M, LAUKO L, BALENTOVA S, PEC J., PEC M et al. Expression pattern of anti-apoptotic protein survivin in dysplastic nevi. Neoplasma 2009; 56: 130-135. http://dx.doi. org/10.4149/neo $2009 \quad 02 \quad 130$

[18] JOHNSON ME, HOWERTH EW Survivin: A Bifunctional Inhibitor of Apoptosis Protein. Vet Pathol 2004; 41: 599-607. http://dx.doi.org/10.1354/vp.41-6-599

[19] BRENNAN DJ, REXHEPAJ E, O'BRIEN SL, MCSHERRY E, O ${ }^{\prime}$ CONNOR DP et al.: Altered cytoplasmic-to-nuclear ratio of survivin is a prognostic indicator in breast cancer. Clin Cancer Res 2008; 14: 2681-2689. http://dx.doi.org/10.1158/1078-0432. CCR-07-1760

[20] SONG KY, JUNG CHK, PARK WS, PARK CHH Expression of the antiapoptosis gene survivin predicts poor prognosis of stage III gastric adenocarcinoma. Jpn J Clin Oncol 2009; 39: 290-296. http://dx.doi.org/10.1093/jico/hyp020

[21] RYAN BM, KONECNY GE, KAHLERT S, WANG H-J, UNTCH M et al. Survivin expression in breast cancer predicts clinical outcome and is associated with HER2, VEGF, uroki- nase plasminogen activator and PAI-1. Ann Oncol 2006; 17: 597-604. http://dx.doi.org/10.1093/annonc/mdj121

[22] HINNIS AR, LUCKETT JC, WALKER RA Survivin is an independent predictor of short-term survival in poor prognostic breast cancer patients. Br J Cancer 2007; 96: 639-645. http://dx.doi.org/10.1038/sj.bjc.6603616

[23] ADAIR F, BERG J, JOUBERT L, ROBBINS GF Longterm follow-up of breast cancer patients: The 30-year report. Cancer 1974; 33: 1145-1150. http://dx.doi. org/10.1002/1097-0142(197404)33:4<1145::AIDCNCR2820330438>3.0.CO;2-0

[24] BLACK MM, BARCLAY THC, HANKEY BF Prognosis in breast cancer utilizing histologic characteristics of the primary tumor. Cancer 1975; 36: 2048-2055. http://dx.doi.org/10.1002/ cncr.2820360919

[25] SUTHERLAND CM, MATHER FJ Long-term survival and prognostic factors in patients with regional breast cancer. Cancer 1985; 55: 1389-1397. http://dx.doi. org/10.1002/1097-0142(19850315)55:6<1389::AIDCNCR2820550638>3.0.CO;2-B

[26] CARTER CL, ALLEN C, HENSON DE Relation of tumor size, lymph node status, and survival in 24, 740 breast cancer cases. Cancer 1989; 63: 181-187. http:// dx.doi.org/10.1002/1097-0142(19890101)63:1<181::AIDCNCR2820630129>3.0.CO;2-H

[27] DOUSSAL VLE, TUBIANA-HULIN M, FRIEDMAN S, HACENE K, SPYRATOS F et al. Prognostic value of histologic grade nuclear components of Scarff-Bloom-Richardson (SBR). An improved score modification based on a multivariate analysis of 1262 invasive ductal breast carcinomas. Cancer 1989; 64: 1914-1921. http://dx.doi. org/10.1002/1097-0142(19891101)64:9<1914::AIDCNCR2820640926>3.0.CO;2-G

[28] TAVASSOLI FA Chapter 5. Benign lesions. In: Stamford, CT, editor. Pathology of the Breast. Second Edition. Hong Kong: Appleton \& Lange, 1999:115-204.

[29] DONEGAN WL, STINE SB, SAMTER TG Implications of extracapsular nodal metastases for treatment and prognosis of breast cancer. Cancer 1993; 72: 778-782. http:// dx.doi.org/10.1002/1097-0142(19930801)72:3<778::AIDCNCR2820720324>3.0.CO;2-I

[30] SNEIGE N, LAGIOS M, SCHWARTING R, COLBURN W, ATKINSON E et al. Interobserver reproducibility of the Lagios nuclear grading system for ductal carcinoma in situ. Hum Pathol 1999; 30: 257-262. http://dx.doi.org/10.1016/S00468177(99)90002-3

[31] KAYASELCUK F, NURSAL TZ, POLAT A, NOYAN T, YILDIRIM $S$ et al. Expression of survivin, bcl-2, p53 and bax in breast carcinoma and ductal intraepithelial neoplasia (DIN 1a). J Exp Clin Cancer Res 2004; 23: 105-111.

[32] NASSAR A, LAWSON D, COTSONIS G, COHEN C Survivin and caspase-3 expression in breast cancer: correlation with prognosis parameters, proliferation, angiogenesis, and outcome. Appl Immunohistochem Mol Morphol 2008; 16: 113-120. http://dx.doi.org/10.1097/ $\underline{\text { PAI.0b013e } 318032 \mathrm{ea} 73}$ 
[33] OH JW, YANG WI, LEE MJ, PARK S, PARK BW et al. The prognostic significance of survivin expression in breast cancer. J Breast Cancer 2009; 12: 285-294. http://dx.doi.org/10.4048/ jbc.2009.12.4.285

[34] CECKA F, HORNYCHOVA H, MELICHAR B, RYSKA A, JANDIK P et al. Expression of bcl-2 in breast cancer: correlation with clinicopathological characteristics and survival. Acta Medica 2008; 51: 107-112.

[35] AL-JOUDI FS, ISKANDAR ZA, HASNAN J, RUSLI J, KAMAL $\mathrm{Y}$ et al. Expression of survivin and its clinicopathological correlations in invasive ductal carcinoma of the breast. Singapore Med J 2007; 48: 607-614.

[36] SOHN DM, KIM SY, BAEK MJ, LIM CW, LEE MH et al. Expression of survivin and clinical correlation in patients with breast cancer. Biomed Pharmacother 2006; 60: 289-292. http://dx.doi.org/10.1016/j.biopha.2006.06.008

[37] RYAN B, O'DONOVAN N, BROWNE B, O'SHEA C, $\mathrm{CROWN} J$ et al. Expression of survivin and its splice variants survivin-2B and survivin- $\Delta \mathrm{Ex} 3$ in breast cancer. $\mathrm{Br} J$ Cancer 2005; 17: 120-124. http://dx.doi.org/10.1038/sj.bjc.6602314

[38] SIMPSON JF, GRAY R, DRESSLER LG, COBAU CD, FALKSON CI et al. Prognostic value of histologic grade and proliferative activity in axillary node-positive breast cancer: results from the Eastern Cooperative Oncology Group Companion Study, EST 4189. J Clin Oncol 2000; 18: 2059-2069.

[39] DRAKE RL, VOGL W, MITCHELL AWM, editors. Grays Anatomy for students. 2nd Edition. Philadelphia: Churchill Livingstone, 2010.

[40] LEE JP, CHANG KH, HAN JH, RYU HS Survivin, a novel anti-apoptosis inhibitor, expression in uterine cervical cancer and relationship with prognostic factors. International Journal of Gynecological Cancer 2005; 15: 113-119. http://dx.doi. org/10.1111/j.1048-891X.2005.15011.x

[41] MEHROTRA S, LANGUINO LR, RASKETT CHM, MERCURIO AM, DOHI T, ALTIERI DC IAP regulation of metastasis. Cancer Cell 2010; 17: 53-64. http://dx.doi. org/10.1016/j.ccr.2009.11.021

[42] ZHANG SQ, QIANG SY, YANG WB, JIANG JT, JI ZZ Expression of survivin in different stages of carcinogenesis and progression of breast cancer. Ai Zheng 2004; 23: 697-700.

[43] ALTIERI DC Survivin, versatile modulation of cell division and apoptosis in cancer. Oncogene 2003; 22: 8581-8589. http://dx.doi.org/10.1038/sj.onc. 1207113

[44] FANGUSARO JR, CALDAS H, JIANG Y, ALTURA RA Survivin: An inhibitor of apoptosis in pediatric cancer. Pediatric Blood \& Cancer 2006; 47: 4-13. http://dx.doi.org/10.1002/ pbc. 20805

[45] REXHEPAJ E, JIRSTROM K, O'CONNOR DP, O'BRIEN SL, LANDBERG G et al. Validation of cytoplasmic-to-nuclear ratio of survivin as an indicator of improved prognosis in breast cancer. BMC Cancer 2010; 10: 639. http://dx.doi. org/10.1186/1471-2407-10-639

[46] BARNES N, HAYWOOD P, FLINT P, KNOX WF, BUNDRED NJ Survivin expression in in situ and invasive breast cancer relates to COX-2 expression and DCIS recurrence. British Journal of Cancer 2006; 94: 253-258. http://dx.doi. org/10.1038/sj.bjc. 6602932

[47] JIN Q, FENG L, BEHRENS C, BEKELE BN, WISTUBA II, HONG W-K, LEE H-Y Implication of AMP-Activated Protein Kinase and Akt-Regulated Survivin in Lung Cancer Chemopreventive Activities of Deguelin. Cancer Res 2007; 67: 11630-11639. http://dx.doi.org/10.1158/0008-5472.CAN-07-2401 